une revue Gallia

Rhône-Alpes | 2007

\title{
Luzinay
}

Pradine la Noyerée III

\section{Tommy Vicard}

\section{(2) OpenEdition}

12 Journals

Édition électronique

URL : http://journals.openedition.org/adlfi/7192

ISSN : 2114-0502

Éditeur

Ministère de la culture

Référence électronique

Tommy Vicard, « Luzinay », ADLFI. Archéologie de la France - Informations [En ligne], Rhône-Alpes, mis en ligne le 01 mars 2007, consulté le 19 avril 2019. URL : http://journals.openedition.org/adlfi/7192

Ce document a été généré automatiquement le 19 avril 2019.

(c) Ministère de la Culture et de la Communication, CNRS 


\section{Luzinay}

Pradine la Noyerée III

\section{Tommy Vicard}

Identifiant de l'opération archéologique : 229688

Date de l'opération : 2007 (EX)

1 Le site de Luzinay offre une belle problématique en géomorphologie avec des zones de dépressions chargées de limon mais ne révèle qu'une structure archéologique : un foyer allant de la période protohistorique à l'Antiquité, posé dans le comblement d'une structure en creux non identifiée.

2 VICARD Tommy

INDEX

Index chronologique : Protohistoire, Antiquité romaine

Index géographique : Rhône-Alpes, Isère, Luzinay

operation expertise (EX)

\section{AUTEURS}

TOMMY VICARD 